\title{
Short Communication: Morphological study of the scales of Barbodes $c f$. binotatus (Cyprinidae) from Toba Lake, Indonesia by using Scanning Electron Microscopy- Energy Dispersive Spectroscopy (SEM-EDS)
}

\author{
KHAIRIZA LUBIS ${ }^{\boldsymbol{\eta}}$, MUFTI SUDIBYO, ELIDA HAFNI SIREGAR, NURLAINI LAILI \\ Department of Biology, Faculty of Mathematics and Natural Sciences, Universitas Negeri Medan. Jl. Willem Iskandar Psr V, Medan 20221, North \\ Sumatra, Indonesia. Tel.: +62-66-14002, Fax.: +62-66-13319, `email: khairizalubis@ unimed.ac.id; khairizalubis15@ gmail.com
}

Manuscript received: 3 June 2021. Revision accepted: 23 August 2021.

\begin{abstract}
Lubis K, Sudibyo M, Siregar EH, Laili N. 2021. Short Communication: Morphological study of the scales of Barbodes cf. binotatus (Cyprinidae) from Toba Lake, Indonesia by using Scanning Electron Microscopy-Energy Dispersive Spectroscopy (SEMEDS). Biodiversitas 22: 3821-3828. Spotted barb (Barbodes cf binotatus) is a freshwater fish of Sumatra Island, especially found in the Toba. The study of morphological characteristics of the scales of Spotted barb (B. cf binotatus) is necessary in fish taxonomy. Therefore, the present study investigated the morphology and the chemical elements of the scales located between the dorsal fin and lateral line and those on the lateral line using SEM-EDS (Scanning Electron Microscope (SEM)- Energy Dispersive X-ray Spectroscopy (EDS). We found that the scales of Spotted barb (B. cf binotatus) have the general morphological characteristics of cycloid scales. The morphologies of the scales between the dorsal fin and lateral line and those on the lateral line are slightly different. Lateral line scales of Spotted barb (B. cf binotatus) have no focus area, replaced by a lateral line canal located along the anterior-posterior axis of the scales with two openings. The anterior opening is bigger and wider in compared to the posterior opening. The circuli of the dorsal fin scale is orientated towards the focus. However, the circuli of the lateral scale faces the lateral line canal. The scales contain some elements such as $\mathrm{Ca}, \mathrm{K}, \mathrm{O}, \mathrm{Mg}, \mathrm{Na}$, and $\mathrm{P}$.
\end{abstract}

Keywords: Barbodes cf binotatus, cycloid scale, scale, SEM-EDS, Toba Lake

\section{INTRODUCTION}

Several methods can be used for identification of animal species such as image recognition systems (IRSs), interactive electronic keys, computer-based morphometric identification (IPez), genetic methods, using of local (folk) expertise, scales, otoliths and hydroacoustics (Omer 2017). The scale morphological characteristics play an important role in the taxonomy field. The macro- and micro structures of fish scales have proved to be a useful tool in fish classification since the early 1900s (Motamedi et al. 2020). In the fishery and taxonomy fields, scales of fish are valuable since they can be used in estimating fish age (Busst 2016), identification (Ibánez and O’Higgins 2011), and phylogenetic information (Khemiri et al. 2001). Fish scales have potential for providing information in environmental studies such as conservation plans and fishery assessment and management (Omer 2017). Fish scales can also be used as a substrate to produce alkaline protease and amino acid rich aqua hydrolyzate by Bacillus altitudinis GVC11, which is suitable for nutritional supplements and organic fertilizer (Harikrishna et al. 2017). Another study reported that fish scales composed of collagen covered with calcium salts have potential for cosmetic, pharmaceutical and biomedical applications (Sionkowska and Kozłowskab 2014).
Most of bony fishes have scales, where the functions of scale are described such as to protect the skin of fish from being getting injured, to give the color of the fish's body and as a sensory receptor with lateral line on the scale which enable the fish to detect wave vibrations in the water (Cartmell 2017). Spotted barb (B. cf binotatus) is originated from Sumatra with a habitat in fresh water at an altitude of 0 to 2000 meters above sea level (Froese and Pauly 2019). In Sumatra Island, Spotted barb (B. cf binotatus) can be found in many places, namely: Maninjau Lake, Toba Lake (Kartamihardja 2019), and Gunung Tujuh Lake (Roesma et al. 2019). Spotted barb (B. cf binotatus) has several local names in Bahasa Indonesia, including wader cakul (Central and East Java), beunteur (West Java), tewaring in Samarinda (Pratama et al. 2018), keperas in Batang Toru, South Tapanuli and pora-pora in Toba Lake village. Spotted barb (B. cf binotatus) is a synonym of Puntius binotatus (Eschmeyer et al. 2018) with the following characteristic: has four barbels; one large blotch at anterior base of dorsal fin and a round spot in the middle of caudal peduncle; color from silvery gray to greenish-gray; darker dorsally; paler or nearly white on throat and belly. It also presents in 10 other countries, namely: Brunei Darsm, Cambodia, Laos, Myanmar, Malaysia, Philippines, Singapore, Thailand, Vietnam, and Palau, but in Singapore and Palau, they are introduced, not native species (Froese and Pauly 2019). 
The application of Scanning Electron Microscopy (SEM) in fish taxonomy especially to identify surface micro-structure of fish scales has been widely used such as for the fishes of the Genus Channa (Dey et al. 2014; Farinordin et al. 2017) and fish families (like Cyprinidae, Channidae, Nandidae) (Farinordin et al. 2017). However, no study on scale morphologies of Spotted barb (B. $c f$ binotatus) from Toba Lake using SEM has ever been reported. Hence, the present research aims to describe the scales morphologies between dorsal-fin base and lateralline row, and lateral line of B. cf binotatus from Toba Lake, North Sumatra, Indonesia using SEM and to determine chemical elements of the scales. Identification of the chemical elements in fish scales is important because fish scales can be a reliable biogeochemical tag for tracing the origin of fishes.

\section{MATERIALS AND METHODS}

\section{Ethical approval}

This experiment was performed on the basis of approval by the research institute and community service of ethics committee of Medan State University, Indonesia, with the ethical approval number: ic220181/ic2rse/lppm/2020.

\section{Scales collection}

The fishes were collected from a natural pond in Pananggangan II Village (Toba Lake) (Figure 1) from July to September 2020 using landing fly fishing net. Ten female fishes of the same size were euthanized for taking the scales. The scales were gently removed with fine forceps from the left side of the body between dorsal-fin base and lateral-line row (Figure 2), and also from the lateral line following the methods of Esmaeili and Gholami (2011).

\section{SEM analysis}

The scales were rinsed with triple distilled water and then treated briefly with $10 \%$ potassium hydroxide solution. The cleaned, scales were dehydrated in 30, 50, 70, and $90 \%$ of ethanol. Furthermore, the scales were examined by a Zeiss Discovery V12 Stereo Zoom Microscope. Then, the scales were mounted on the metallic stubs by double adhesive tape and coated with a thick layer of colloidal graphite (AGG303 (Aquadag 500 gr). The observation using SEM-EDS followed the method of Lippitsch (1990).

\section{RESULTS AND DISCUSSION}

\section{Description of the scales between dorsal-fin base and lateral-line row}

There are two types of scales between dorsal fin baselateral line row and lateral-line scale due to differences in the center part (Figure $3 a$ and $3 b$ ), the radii of the first type have no pattern (Figure 4a), whereas the second type has radii with an irregular mosaic pattern (Figure 4b) containing granules of various shapes and sizes. Radii were found on the anterior/rostral, lateral and posterior of the scale. The anterior/rostral side of both types of scales has interradial tongues that are wavy and notched (Figure 4c), consisting of the circuli, intercircular space, and lepidonts. However, the posterior side contains a tubercle (Figure 4c). Each circuli is separated from the other by the intercircular space (Figure 4d). Lepidonts can be found on the circuli, which are presented in a variety of shapes and sizes (Figure 4d).

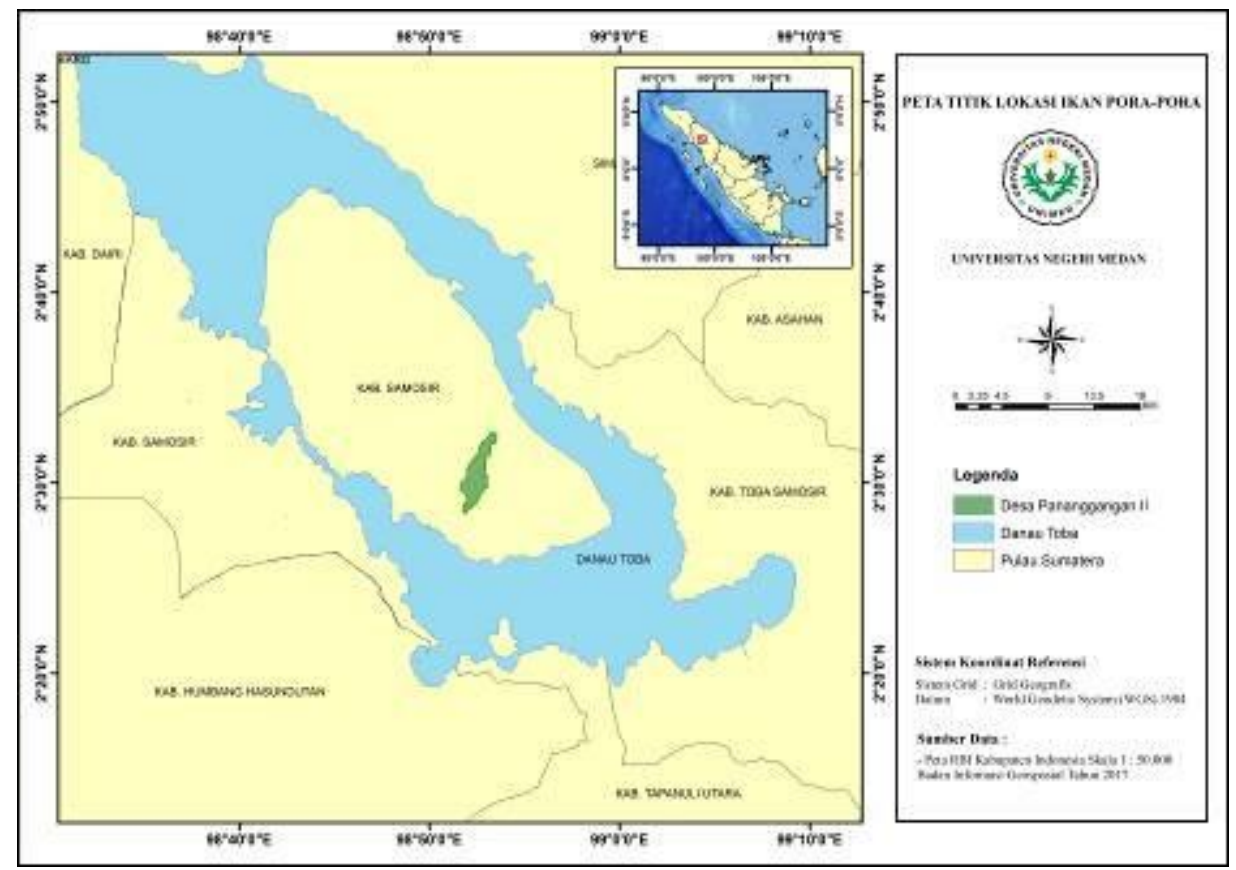


Figure 1. Sampling location

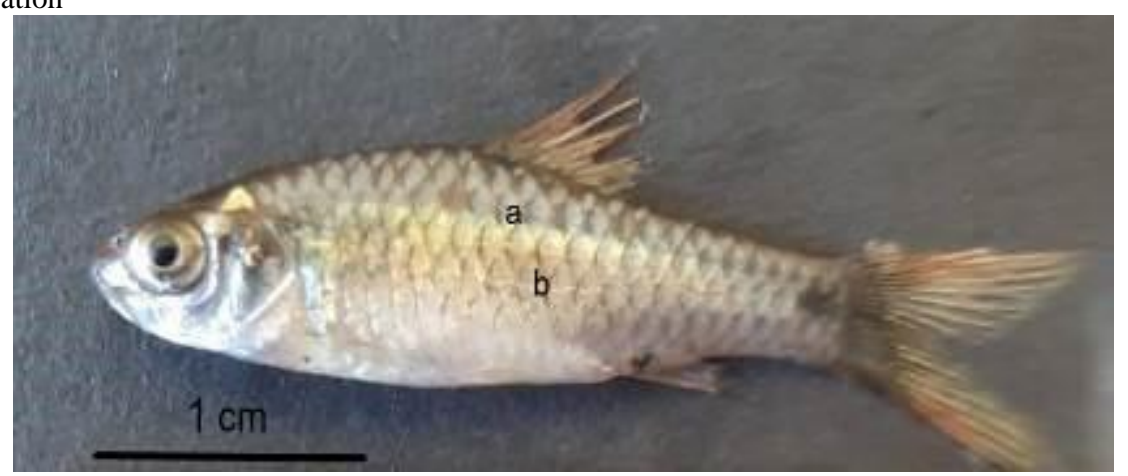

Figure 2. The location of fish scale collection
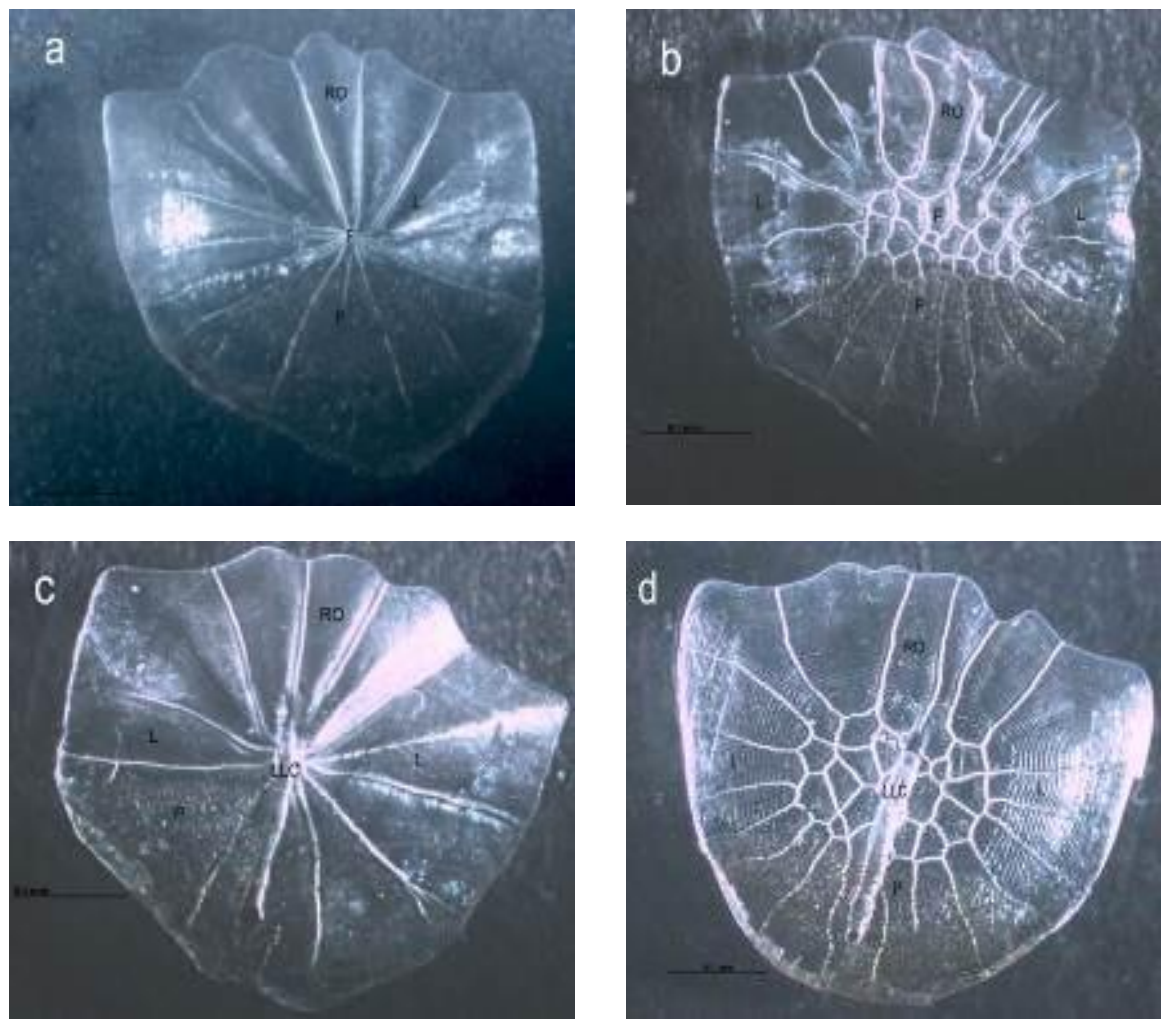

Figure 3 (a-d). Photograph of scales between dorsal-fin base and lateral-line row (a-b) and lateral line scale (c-d). Rostral/anterior (RO), lateral (L), posterior (P), focus (F), lateral line canal (LLC) by using Zeiss Discovery V12 Stereo Zoom Microscope

The lateral part has circuli and lepidonts (4e). The circuli of scales between dorsal-fin base and lateral-line row faces the focus. The separation between the lateral and posterior parts is characterized by a reduction in the number of circuli and widening of the intercirculi, while the posterior area consists of the tubercles and mucous pore (Figure 4e). Posteriorly, we found many tubercles with varying shapes.

\section{Description of the lateral-line scale row}

There are two types of lateral line scales due to variations at the center part (Figure $3 \mathrm{c}$ and $3 \mathrm{~d}$ ). Therefore, the radii structures of the two types of lateral line scales are also different. The radii of the first type of focus scale do not have a pattern ( $5 a$ and $5 b$ ), while those of the second type of scale have an irregular mosaic pattern (Figure 5c), granulated with various shapes and sizes (Figure $5 \mathrm{~d}$ ). The focus area of the lateral line scale is replaced by a lateral line canal. The ends of the anterior and posterior parts of the lateral line canal have openings called the anterior opening line canal and the posterior opening line canal respectively. The anterior opening is bigger and wider than the posterior opening, while the posterior opening is more circular (Figure 5e and 5f). The circuli were oriented towards the lateral line canal, containing lepidonts of blunt 
tooth shape and various sizes (Figure $5 \mathrm{~g}$ and $5 \mathrm{~h}$ ). Tubercles and mucous pore can be seen posteriorly (Figure $5 \mathrm{i}-5 \mathrm{j}$ ).
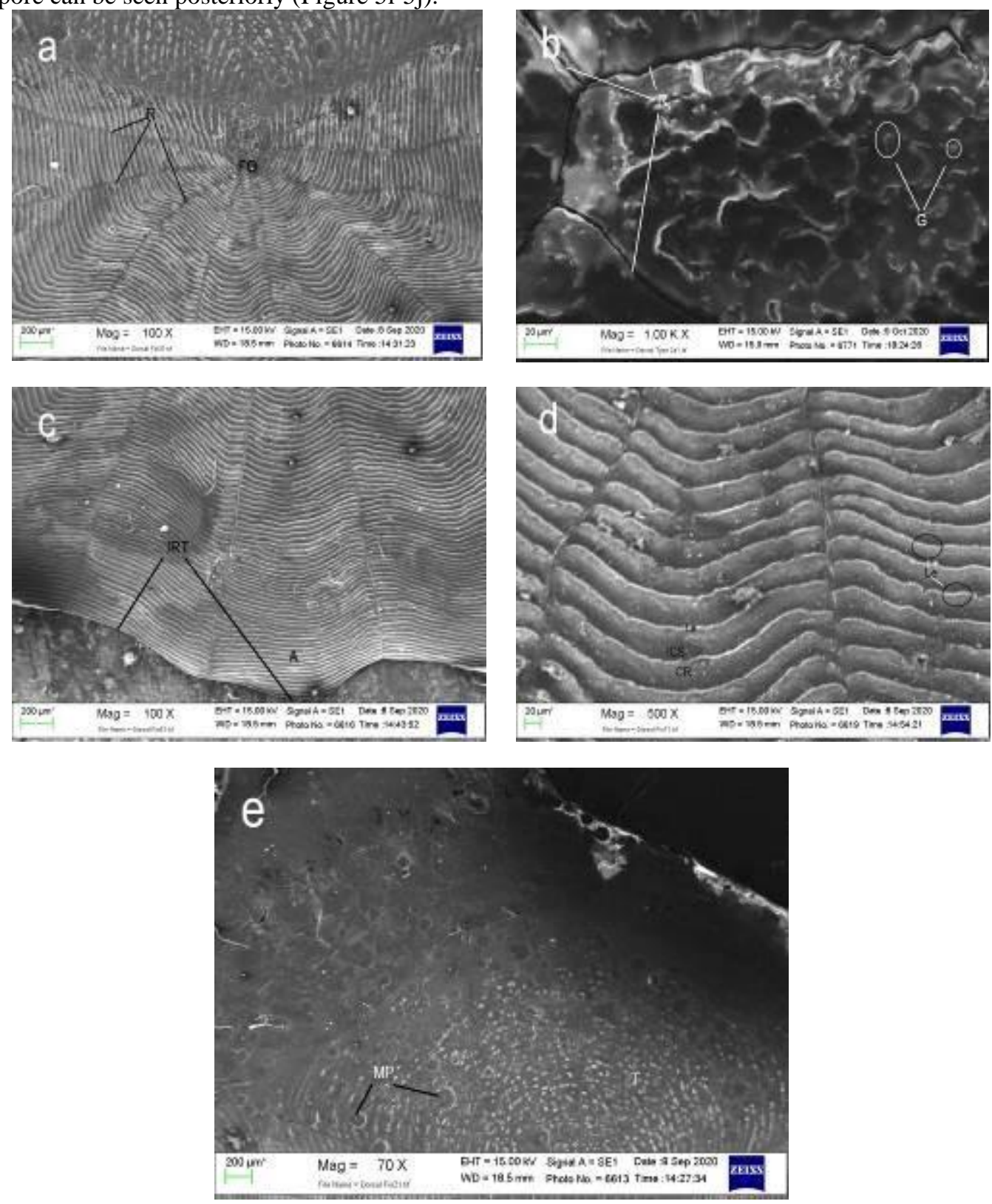

Figure 4 (a-e). SEM morphology of scales between dorsal-fin base and lateral-line row of Spotted barb (B. cf binotatus). Radii (R), granule (G), interradial tongues (IRT), circuli (CR), anterior (A), intercirculi space (ICS), interradial (IRC), lepidont (Le), focus (FO), mucous pore (MP), tubercle $(\mathrm{T})$, posterior $(\mathrm{P})$ 






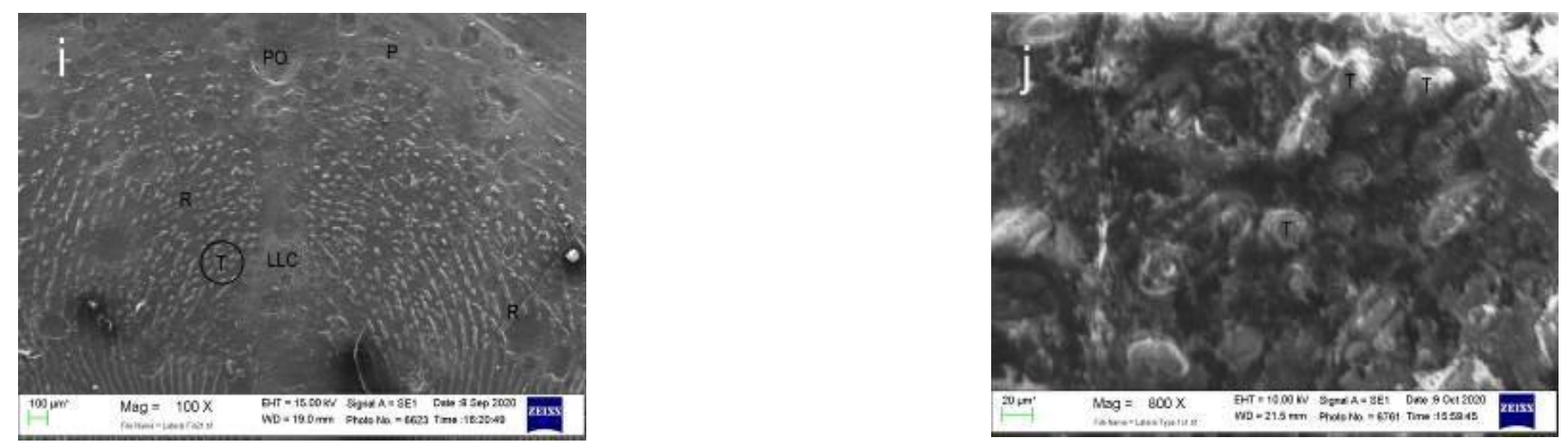

Figure 5 (a-j). SEM morphology of lateral line scale of Spotted barb (B. cf binotatus). Circuli (CR), anterior (A), radii ( R), intercirculi space (ICS), lepidont (Le), fokus area (FO), lateral line canal (LLC), anterior opening (AO), posterior openimg (PO), tubercle (T), posterior $(\mathrm{P})$

\section{SEM-EDS analysis}

The result of SEM-EDS analysis revealed that the scales between dorsal-fin base and lateral-line row, and lateral line scales contain several elements (Figure 6a and 6b). The lateral line scales of Spotted barb (B. cf binotatus) consist of calcium $(\mathrm{Ca})$, potassium $(\mathrm{K})$, oxygen $(\mathrm{O})$, magnesium $(\mathrm{Mg})$, sodium $(\mathrm{Na})$ and phosphorus $(\mathrm{P})$, whereas $\mathrm{Na}$ is unavailable in scales between dorsal-fin base and lateral-line row. The carbon of both scales might be from the coating process of SEM.

\section{Discussion}

Micro-structural components of fish scales, such as the focus, chromatophores, radii, circuli, lepidonts, and the region below focus, are considered to be of taxonomic



significance (Dey et al. 2014). In our study, we found two different types of patterns at the center of each the dorsal fin and lateral line scales. The center of the scales is between dorsal-fin base and lateral-line row, which is called as the focus. The first type of the scales between dorsal-fin base and lateral-line row has radii directly faces the focus, such as forming a central point (without a pattern). Meanwhile, the second type has radii that lead to the focus, forming an irregular mosaic pattern. Previous study also reported that the scales between dorsal-fin base and lateral-line row type of Spotted barb (B. cf binotatus), Puntius lateristriga, and Hampala macrolepidota (Hampala Barb) from Malaysia with different patterns on the focus (Farah-ayuni 2016).



Figure 6. SEM-EDS Image of the scales between dorsal-fin base (a) and and lateral-line row (b)

The second type of Spotted barb (B. $c f$ binotatus) scales which are from Toba Lake, showing both the scales between dorsal-fin base and lateral-line row, and lateral line scales with irregular mosaic patterns (irregular mosaic). Fish scales with irregular mosaic patterns were also found in Sparisoma cretense (Parrotfish) and Thalassoma pavo (Brager and Moritz 2016). Another study reported that an irregular mosaic pattern of fish scale is a characteristic of regenerating scales (Kabir 2021). Reported in the lateral line scale of Neolissochilus hexagonolepis and Neolissochilus hexastichus (Nongrum and Bhuyan 2020). Morphological variations of scales on the body of a fish are often found not only in Spotted barb (B. cf binotatus), but also in other cyprinid species such as Cyprinus carpio, Barbonymus gonionotus, Barbonymus schwanenfeldii, Labeo rohita, Cyclocheilichthys apogon (Farinordin et al. 
2017), and Scardinius racovitzai (Șerban and Grigoras 2018). The differences in scales' morphological characteristics in each part of the fish body are very important for taxonomic identification in each species (Kontas et al. 2020). Spotted barb (B. cf binotatus) scales that we found were similar to Farah-ayuni (2016) study, namely: cycloid type; radii cover at anterior, posterior and lateral, radii arrangement is uniform; interradial tounge structure is irregular and serrated; focus position is in the middle of scale.

The Scanning Electron Microscopy results in our study showed that Spotted barb (B. cf binotatus) have the general morphological structure of a cycloid scale type, i.e. presence of focus, circuli, intercirculi, radii, tubercles, and lepidont, which is similar to Garra rossica (Esmaeili et al. 2012). Base of scales between dorsal-fin base and lateralline row, and lateral line scales of $B$. cf binotatus in our study has pentagonal shaped with curved and wavy at anterior sides, more or less the similar to the both of sexes of Spotted barb (B. cf binotatus) from Salug Valley River of Zamboanga del Sur, Philippines, which is a cycloid scale with elliptic, oblong, pentagonal, rectangular, square, and triangular shapes on the base of their scales (Ganzon 2012). The scales between dorsal-fin base and lateral-line row have circuli which is grooved, tight and form a convex line and also forms a straight transverse line starting from the rostral edge of the focus area. Circuli on the scales are clearly visible anteriorly and laterally and not present at posterior. The appearance of circuli is as a result of the accumulation of calcium released by the skin. Therefore, the distance between circuli reflects the fast and slow periods of growth (Ganzon 2012). Lepidonts are also found on the scales of Spotted barb (B. $c f$ binotatus). The structures of lepidonts on the scales of Spotted barb (B. $c f$ binotatus) like denticles or blunt teeth, located in the anterior part of the circuli that have various shapes and sizes. Radii on the scales between dorsal-fin base and lateral-line row, and lateral line scales are found on the anterior, lateral and posterior, which are shaped like a straight line that leads radially to the focus area. Radii serve as a separator between each circuli. Radii consists of several types, namely primary radii, secondary radii and tertiary radii, which can provide information about the growing conditions of fish (Esmaeili et al. 2012). In addition, tubercles can be seen on the posterior side of Spotted barb (B. $c f$ binotatus) scales with various shapes. The tubercles are formed due to an aggregation of the epithelial layer of the skin that covers the posterior part of the scales, which results in the appearance of a specific color in the fish since it contains chromatophores on its outer surface (Esmaeili et al. 2012).

Contrary to the center of scales between dorsal-fin base and lateral-line row, the center of a lateral line scales consists of canal, which is located along the anterior and posterior axes of the scales. The anterior and posterior ends of the line canal are composed of two holes that are called as the anterior opening line canal and the posterior opening line canal, functioning as mechano-sensory. The mechanosensory system can provide information about the existence and identity of prey and predators and as a means of receiving communication signals between fish (Edgley and Genner 2019). Differences in the center of the scales between dorsal-fin base and lateral-line row, and lateral line scales are common. Some studies reported that the scale varying morphologies of cyprinids and other fish species between body regions and between species can be occurred (Kontas et al. 2020).

As described in the results, the scales between dorsalfin base and lateral-line row, and lateral line scales of $B . c f$ binotatus that were observed using SEM-EDS contained some elements, namely: $\mathrm{O}, \mathrm{Ca}, \mathrm{P}, \mathrm{Mg}, \mathrm{K}$, and $\mathrm{Na}$. However, $\mathrm{Na}$ element did not present in the dorsal fin scale. Different species contain different elements of scales, for example, the scales of Barilius bendelensis, which of the same family as Spotted barb (B. cf binotatus), exhibit different elements compared to the scales of Spotted barb (B. cf binotatus) which are $\mathrm{Ca}, \mathrm{P}, \mathrm{Mg}, \mathrm{C}$ (carbon), $\mathrm{Na}$ (sodium), $\mathrm{Fe}$ (iron), $\mathrm{Cl}$ (chlorine) and $\mathrm{S}$ (sulfur) (Thomas 2019). Thomas (2019) also reported that the elements of the various parts of these scales can help in differentiating population habitat conditions, determining fish life history, and sexual dimorphism.

We conclude that Spotted barb (B. cf binotatus) from Toba Lake is of the cycloid type with two different patterns at the center of both the scales between dorsal-fin base and lateral-line row, and lateral line scales. The elements of $\mathrm{Ca}$, $\mathrm{K}, \mathrm{O}, \mathrm{Mg}, \mathrm{Na}$ and $\mathrm{P}$ were found in both scales, except $\mathrm{Na}$ element undetected in the scales between dorsal-fin base and lateral-line row. Based on these results, SEM images of the scales of Spotted barb (B. cf. binotatus) are a reliable tool in fish scales morphological description, which is useful in taxonomy study and also can be used to observe the breakage of the circuli.

\section{ACKNOWLEDGEMENTS}

The authors are thankful to Universitas Negeri Medan for the financial support in 2020 budget year, No. 0441/UN33/KEP/PPL/2020, June, $15^{\text {th }} 2020$.

\section{REFERENCES}

Bräger Z, Moritz T. 2016. A scale atlas for common Mediterranean teleost fishes. Vertebr Zool 66 (3): 275-386. Published online at www.senckenberg.de /vertebrate-zoology on 13.xii.2016.

Busst GMA. 2016. Fish Scales as Ecological Indicators: Empirical Approaches to Improve Their Practical Application to Fish Ecology. [Thesis]. Bournemouth University, Bournemouth, United Kingdom.

Cartmell P. 2017. What are fish scale functions? https://animals.mom.com/what-are-fish-scale-functions4129749.html, accessed August, $1^{\text {st }}, 2021$.

Dey S, Biswas SP, Dey S, Bhattacharyya SP. 2014. Scanning Electron Microscopy of scales and its taxonomic application in the fish Genus Channa. Microscopy Microanal 20: 1188-1197. DOI: 10.1017/S1431927614001019

Edgley ED, Genner MJ. 2019. Adaptive diversification of the lateral line system during Cichlid fish radiation. iScience 16: 1-11. DOI: 10.1016/j.isci.2019.05.016

Eschmeyer WN, Fricke R, van der Laan R. 2018. Catalog of fishes: genera, species. http://researcharchive.calacademy.org/research/ichthyology/catalog/fishcatmain.asp. 
Esmaeili HR, Gholami Z. 2011. Scanning electron microscopy of the scale morphology in Cyprinid fish Rutilus frisii kutum Kamenskii, 1901 (Actinopterygii: Cyprinodontidae). Iranian J Fish Sci 10 (1): 155-166.

Esmaeili HR, Gholamifard A, Zarei N, Arshadi A. 2012. Scale structure of a cyprinid fish, Garra rossica (Nikol'skii, 1900) using scanning electron microscope (SEM). Iranian J Sci Technol A4: 487-492.

Farah-Ayuni F, Muse AO, Samat A, Shukor MN. 2016. Comparative scale morphologies in common freshwater fishes of Peninsular Malaysia-A case study. AIP Conf Proc 1784: 060012. DOI: 10.1063/1.4966850

Farinordin FA, Nilam WSW, Husin SM, Samat A, Md. Nor S. 2017. Scale morphologies of freshwater fishes at Tembat Forest Reserve, Terengganu, Malaysia. Sains Malaysiana 46 (9): 1429-1439. DOI: 10.17576/jsm-2017-4609-11

Froese R, Pauly D. 2019. Barbodes binotatus (Valenciennes, 1842). FishBase. binotatus.html.

Ganzon MAM, Torres MAJ, Gorospe JJ, Demayo CG. 2012. Variations in scale morphology between sexes of the spotted barb, Puntius binotatus (Valenciennes, 1842) (Actinopterygii: Cyprinidae). Intl Conf Environ Biosci 44: 80-84. DOI: 10.7763/IPCBEE. 2012. V44. 17

Harikrishna N, Mahalakshmi S, Kumar KK, Reddy G. 2017. Fish scales as potential substrate for production of alkaline protease and amino acid-rich aqua hydrolyzate by Bacillus altitudinis GVC11. Indian J Microbiol 57 (3): 339-343. DOI: 10.1007/s12088-017-0664-2

Ibánez AL, O’Higgins P. 2011. Identifying fish scales: The influence of allometry on scale shape and classification. Fish Res 109: 54-60. DOI: 10.1016/j.fishres.2011.01.016

Kabir AKMN. 2021. Fish scales: Types, development and functions. https://biologyeducare.com/fish-scales/.

Kartamihardja ES. 2019. Keberhasilan introduksi ikan bilih (Mystacoleucus padangensis Blkr) di Danau Toba perlu pemulihan. Warta Iktiologi 3 (1): 1-8. [Indonesia]

Khemiri S, Meunier FJ, Laurin M, Zylberberg L. 2001. Morphology and structure of the scales in the Gadiformes (Actinopterygii: Teleostei:
Paracanthopterygii) and a comparison to the elasmoid scales of other Teleostei. Cahiers de Biologie Marine 42 (4): 345-362.

Kontas S, Yedier S, Bostancr D. 2020. Otolith and scale morphology of endemic fish Cyprinion macrostomum in Togris- Euphrates Basin. J Ichthyol 60 (4): 562-569. DOI: 10.1134/S0032945220040086

Lippitsch E. 1990. Scale morphology and squamation patterns in cichlids (Teleostei, Perciformes): A comparative study. J Fish Biol 37: 265291. DOI: 10.1111/j.1095-8649.1990.tb05858.x

Motamedi M, Teimori A, Amiri V, Hesni MA. 2020. Characterization of age-dependent variability in the flank scales of two scorpaeniformes fishes by applying light and scanning electron microscopy imaging. Micron 128: 102778. DOI: 10.1016/j.micron.2019.102778

Nongrum R, Bhuyan RN. 2020. Comparative study of fish scale using scanning electron microscopy in two Cyprinid fishes (Neolissochilus hexagonolepsis and Neolissochilus hexastichus) found in Meghalaya, North- East India. J Life Sci 8 (1): 77-82.

Omer AS. 2017. Review on fish identification tools and their importance in biodiversity and fisheries assessments. Int J Sci Basic Appl Res 36 (6): 118-126.

Pratama R, Jusmaldi, Nova H. 2018. Pola pertumbuhan, faktor kondisi dan habitat ikan tewaring Barbodes binotatus (valenciennes, 1842) di Sungai Hutan Berambai Samarinda. Bioprospek 13 (1): 40-49. DOI: 10.30872/bp.v13i1.205. [Indonesia]

Roesma DI, Tjong DH, Karlina W, Aidil DR. 2019. Taxonomy confirmation of Puntius cf. Binotatus from Gunung Tujuh Lake, Jambi, Indonesia based on Cytochrome Oxidase-I (COI) gene. Biodiversitas 20 (1): 54-60. DOI: 10.13057/biodiv/d200107

Serban C, Grigoras G. 2018. Structural and morphometric study of scales in Petzea Rudd (Scardinius racovitzai Müller 1958). Appl Ecol Environ Res 16 (5): 6063-6076. DOI: 10.15666/aeer/1605_60636076

Sionkowska A, Kozłowskab J. 2014. Fish scales as a biocomposite of collagen and calcium salts. Key Eng Mat 587: 185-190. DOI: 10.4028/www.scientific.net/KEM.587.185

Thomas N. 2019. Sexual dimorphism in Barilius bendelisis (Hamilton, 1822) based on scale structure as revealed by SEM and EDX Studies. Intl J Multi Res Publ 2 (5): 48-54. 